\title{
Method for Environmental Flows Regulation and Early Warning with Remote Sensing and Land Cover Data
}

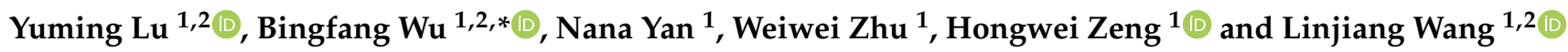 \\ 1 State Key Laboratory of Remote Sensing Science, Aerospace Information Research Institute, \\ Chinese Academy of Sciences, Beijing 100101, China; luym@aircas.ac.cn (Y.L.); yannn@aircas.ac.cn (N.Y.); \\ zhuww@aircas.ac.cn (W.Z.); zenghw@aircas.ac.cn (H.Z.); wanglj@radi.ac.cn (L.W.) \\ 2 College of Resources and Environment, University of Chinese Academy of Sciences, Beijing 100049, China \\ * Correspondence: wubf@aircas.ac.cn; Tel.: +86-10-6485-5689
}

check for updates

Citation: Lu, Y.; Wu, B.; Yan, N.; Zhu, W.; Zeng, H.; Wang, L. Method for Environmental Flows Regulation and Early Warning with Remote Sensing and Land Cover Data. Land 2021, 10 , 1216. https://doi.org/10.3390/ land10111216

Academic Editors:

Ebrahim Ahmadisharaf, Vamsi Krishna Sridharan and Saurav Kumar

Received: 25 October 2021

Accepted: 9 November 2021

Published: 10 November 2021

Publisher's Note: MDPI stays neutral with regard to jurisdictional claims in published maps and institutional affiliations.

Copyright: (c) 2021 by the authors. Licensee MDPI, Basel, Switzerland. This article is an open access article distributed under the terms and conditions of the Creative Commons Attribution (CC BY) license (https:/ / creativecommons.org/licenses/by/ $4.0 /)$.

\begin{abstract}
Environmental flows play a vital role in ecosystem and water resource management. The regulation and management of environmental flows can improve the function and stability of river and lake ecosystems. However, current methods for assessing environmental flows mainly emphasize water management, and there is no complete set of regulations or early warning systems, especially in arid and semiarid basins. In this study, we proposed a method for environmental flows regulation and early warning with remote sensing and land cover data and carried out a case study in the Yongding River Basin, which is a basin typical of arid and semiarid areas. The results show that from 2001 to 2014 the mean precipitation was $17.90 \times 10^{9} \mathrm{~m}^{3}$, and the mean water consumption was $19.42 \times 10^{9} \mathrm{~m}^{3}$, indicating that the basin water budget was clearly unbalanced and that there was an overall deficiency. Notably, from 2005 to 2014 and in 2014, the available consumable water was less than the water consumption required for human activities, which both showed a trend of further reduction; therefore, long-term and annual early warnings should have been issued. The methods applied in this study and the study outcomes could help in the development of comprehensive management and ecological restoration plans, further improving the ecological environments of river basins.
\end{abstract}

Keywords: environmental flows; remote sensing; land cover; early warning; Yongding River Basin

\section{Introduction}

Water is a basic requirement for the sustainable economic and social development of inhabitants of basins and is fundamental for maintaining optimal ecological environments and allowing ecosystems to thrive [1-3]. Rivers play a pivotal role in natural ecosystems and are essential for supporting ecological functions. Basins are catchment areas for rivers and lakes and other water systems. They are the basic spatial unit considered in water resource and environment planning and management [4]. Environmental flows play a critical role in ecosystem restoration and water resource management [5-7]. River ecosystems are affected by changes in environmental flows. Effective management of environmental flow resources is the key to optimizing environmental functions $[4,8]$.

As global climate change and the effects of human activities intensify, effective management of environmental flows as the basin scale seems to be a common problem. There are few natural basins, and the physical process and mechanisms by which the water cycle is transformed have also undergone tremendous changes [9,10]. The Beijing-Tianjin-Hebei region is a crucial economic zone in China, and the Yongding (YD) River Basin is an important water conservation area and ecological barrier in this region. However, due to the effects of climate change and human activities, there are serious ecological problems in the YD River Basin, such as water resource overexploitation, water pollution and unbalanced water supply, which have led to severe ecological function degradation [11,12]. 
Existing water resource evaluation methods rely heavily on field-based observations, focusing on surface and underground streamflow, which accounts for approximately $20-30 \%$ of precipitation ( $60 \%$ in humid areas) [13-15]. However, little attention has been given to evapotranspiration (ET) and water consumption in basins, which account for $70-80 \%$ of precipitation, causing previous studies to underestimate the water cycle elements; therefore, comprehensive and accurate water resource information cannot be determined, the urgent need to fully grasp the overall state of water resource development and utilization cannot be fulfilled, and the scientific management and control of water resources cannot be strengthened. With the application and maturity of remote sensing technology, the accuracy of quantitative inversion models for precipitation and ET has improved, and breakthroughs have been made in the application of remote sensing to the management of water resources. One of the crucial innovative results of previous studies is the proposal of the concept of water consumption management [16].

Considering the entire water cycle in a basin, the consumption of water by ET plays an essential part in hydrological processes. When ET exceeds the upper limit of water resources in a basin, a series of problems such as shrinking rivers and lakes, overexploitation of groundwater, and deterioration of the ecological environment, will arise Given the increasingly scarce water resources, controlling and reducing river basin ET, setting reasonable basin target ET levels $[17,18]$, and carrying out ET management have become important aspects of river basin water resource management $[16,19,20]$. ET is affected by not only natural features such as climate, topography, and vegetation but also human activities such as cropland reclamation and irrigation [21], which have both natural and artificial attributes. Depending on its cause, ET can be decomposed into ET driven by natural causes and ET driven by human activity, where the former is the amount of precipitation consumed by natural surface-level processes and the latter $[16,22]$ is the additional water consumed by human activities $\left(\mathrm{ET}_{\mathrm{h}}\right)$, such as farming, irrigation, and evaporation of water from reservoirs $[23,24]$. Therefore, understanding the patterns of water consumption and conducting water consumption analyses is the basis for the management of ET in entire basins and can help promote the sustainable development of water resources.

$\mathrm{Wu}$ [16] proposed four steps for water resource management after summarizing water consumption management practices in the Haihe River Basin: analysis of water consumption balance at the basin scale, calculation of target water consumption (ET) based on sustainable goals, distribution of ET among various water users and evaluation of watersaving potential and water-saving effect. Agriculture, as a major consumer of water, is the most concerning factor when addressing the problem of water shortages. Grafton [25] discussed the problem associated with high irrigation efficiency rarely reducing water consumption in a description of the paradox of irrigation efficiency. Bob [26] and Brebbia [27] emphasized the need to comprehensively carry out water resource management and highlight its rationality and sustainability. Sun [28] and Poff $[29,30]$ proposed new frameworks and methods with which to assess environmental flows to promote water resource management. As an important strategic resource, the sustainable use of water resources must be ensured, and water resource management systems must be improved.

As early as the 1970s, Germany proposed the initial concept of early warning. The concept of regional early warning systems for ecological environments was proposed by $\mathrm{Fu}$ [31]. Water consumption and water demand are essential to environmental flows, and this field of study is maturing, due to the development of a wealth of relevant methods and algorithms [32-37]. However, the combination of water consumption analysis and environmental flow warning in a given basin has rarely been studied directly. We address this gap by analyzing water supply and consumption and monitoring available consumable water $(\mathrm{ACW})$ in a basin.

Previous research on environmental flows has been largely based on water consumption methods or models [38-40]. The major objective of this study is to propose a method to analyze the water consumption in a complete environmental flow system, including the water supply and use, through the water balance relationship in the basin to obtain 
the actual water consumption, to analyze the ACW, and to provide long-term and annual early warning of environmental flow issues based on the difference between the ACW and $\mathrm{ET}_{\mathrm{h}}$. This study should make an important contribution to the field of the supervision, management, scheduling, and organization of environmental flows to improve ecological environments.

\section{Data and Study Area}

\subsection{Study Area}

The YD River Basin is located in the northwestern Haihe River Basin, stretching from $39^{\circ}$ to $42^{\circ} \mathrm{N}$ and $112^{\circ}$ to $118^{\circ} \mathrm{E}$, and covers an area of approximately $47,000 \mathrm{~km}^{2}$ (Figure 1). The YD River Basin originates from the southern edge of the Inner Mongolia Plateau and the northern Shanxi Plateau. To the east of the YD River Basin is Chaobai, a northern canal system, and the Yellow River Basin is to the west; the Daqing River system is located to the south, and an inland river is to the north [41,42]. This basin has a temperate continental monsoon climate, with large seasonal differences and various climatic changes, and is located in a transition zone between semi-humid and semiarid climates. The precipitation in the basin follows an obvious regional pattern, and large regional differences in precipitation are apparent.

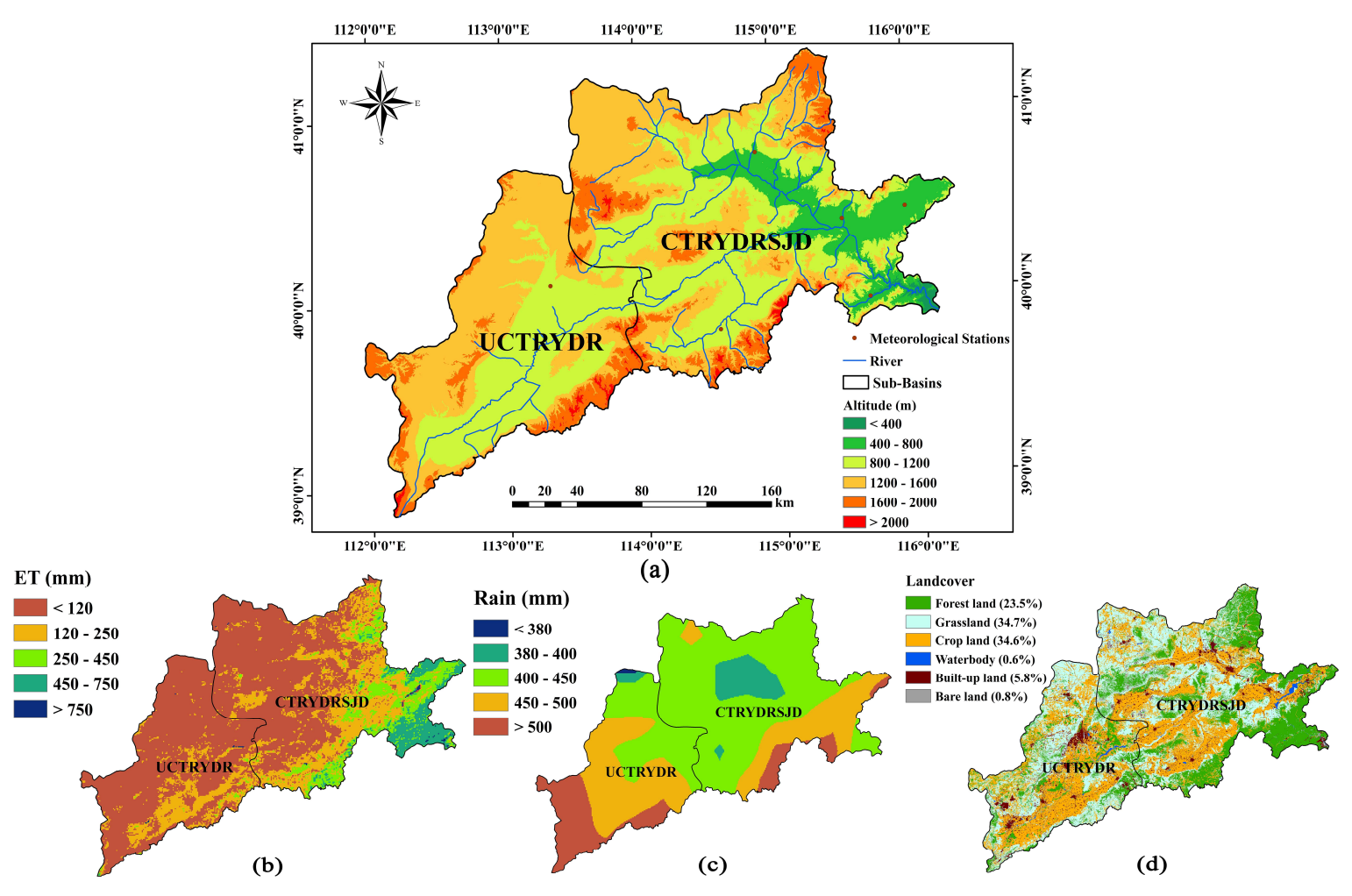

Figure 1. (a) Locations and altitudes of the YD River Basin, meteorological stations and rivers; (b) ET distribution map; (c) rainfall distribution map; (d) land cover map of the YD River Basin.

The YD River Basin includes large tributaries of the Sanggan River and Yanghe River and involves sub-basins, including the region upstream of the Cetian Reservoir of the YD River (UCTRYDR) and the region encompassing the area from the Cetian Reservoir of the YD River to Sanjiadian (CTRYDRSD). The water use by the upstream agricultural production is extensive, and the planting structure is unsustainable. Agricultural water consumption accounts for $66 \%$ of the total water consumption (TWC) [11]. The downstream plain river channel became completely dry after 1996; the riverbed in some sections was sanded, the groundwater level dropped, and the ground subsided. Our study is mainly based on the analysis of the UCTRYDR and CTRYDRSD. 


\subsection{Data}

The main data used in this study include remote sensing and site precipitation datasets, remote sensing-based ET data, land cover data and annual streamflow datasets.

\subsubsection{Precipitation Data}

The precipitation datasets for the YD River basin for the period from 2001 to 2018 and were obtained by combining data from the Tropical Rainfall Measuring Mission (TRMM) and ground-based rainfall stations. TRMM annual precipitation data were synthesized from TRMM 3B43 monthly precipitation data with a spatial resolution of $0.25^{\circ}[43,44]$. The remote sensing-based precipitation estimation product can approximately reflect the spatial distribution of precipitation intensity, but its spatial resolution is relatively coarse, and the associated estimations have a certain error. Hence, the advantages of a highly accurate remote sensing-based precipitation estimation product and ground-based data can be integrated using spatial fusion to obtain estimation results with relatively high accuracy [45]. To further improve the accuracy of the annual precipitation estimation, in this study, geographical differential analysis was used to obtain the final annual precipitation dataset and the bilinear spatial interpolation method was used to resample the final dataset at a $1 \mathrm{~km}$ spatial resolution.

\subsubsection{Remote Sensing Based Evapotranspiration Data}

The ETWatch system was used to estimate ET data with a $1 \mathrm{~km}$ spatial resolution from 2001 to 2018 [16,46]. ETWatch is an ET monitoring system based on the surface energy balance and Penman-Monteith equation; the system is composed of data acquisition, data preprocessing, ET monitoring, ET application and data management modules [16,46]. ETWatch uses remote sensing-based monitoring, reanalysis, and site-measured data as inputs, and calculates ET based on the energy balance residual method [46]. Jia [47] and $\mathrm{Wu}$ [48] carried out a large number of verifications of this approach at different spatial scales. The annual deviations at the basin scale, field scale, and sub-basin scale were less than $1.8 \%, 3.0-9.0 \%$ and $3.8 \%$, respectively.

\subsubsection{Land Cover and Land Use Data}

The land cover and land use products for 2000, 2005, 2010, and 2015 were from China Land Cover datasets ( $30 \mathrm{~m}$ spatial resolution). To be consistent with the resolution of the precipitation and ET data, the majority sampling method was adopted to resample the land cover and land use products to a $1 \mathrm{~km}$ spatial resolution. Previously, Landsat TM/ETM data and Chinese HJ-1 satellite data were used to map land cover, with the acquired images classified into forestlands, grasslands, croplands, wetlands, built-up lands and other lands [49]. The overall accuracy of the first-class China Land Cover data exceeded 94\% [50], and the overall accuracy of the second-class data exceeded 86\% [51]. The relative accuracy of ChinaCover data is high; therefore, it can be used to estimate water consumption in different land cover types [25].

\subsubsection{Other Data}

Hydrological data and streamflow data for the sub-basins in the YD River Basin for 2001 to 2018 were obtained from the Haihe River Water Conservancy Commission (HWCC, http:/ / hwcc.gov.cn, accessed on 30 June 2020).

\section{Methods}

Combining all the data mentioned in Section 2, we used ET to conduct a water resource management and water consumption analysis based on the principle of hydrological water balance. The starting point is based on the whole water cycle, and the management object is the total water vapor flux. This principle is based on the relationship between the supply and consumption of water resources in the basin. We used the ET-based balance equation to analyze the water consumption of the basin, obtain the human water consumption, 
and obtain the natural water consumption (NWC) based on total ET monitoring and land cover. Then, the ACW for human activities was obtained through the direct relationship between the total precipitation of the basin, the NWC and the uncontrollable runoff. Finally, environmental flow early warning research was carried out by comparing and calculating the water consumption and ACW for human activities. The structure of this method is shown in Figure 2 below.

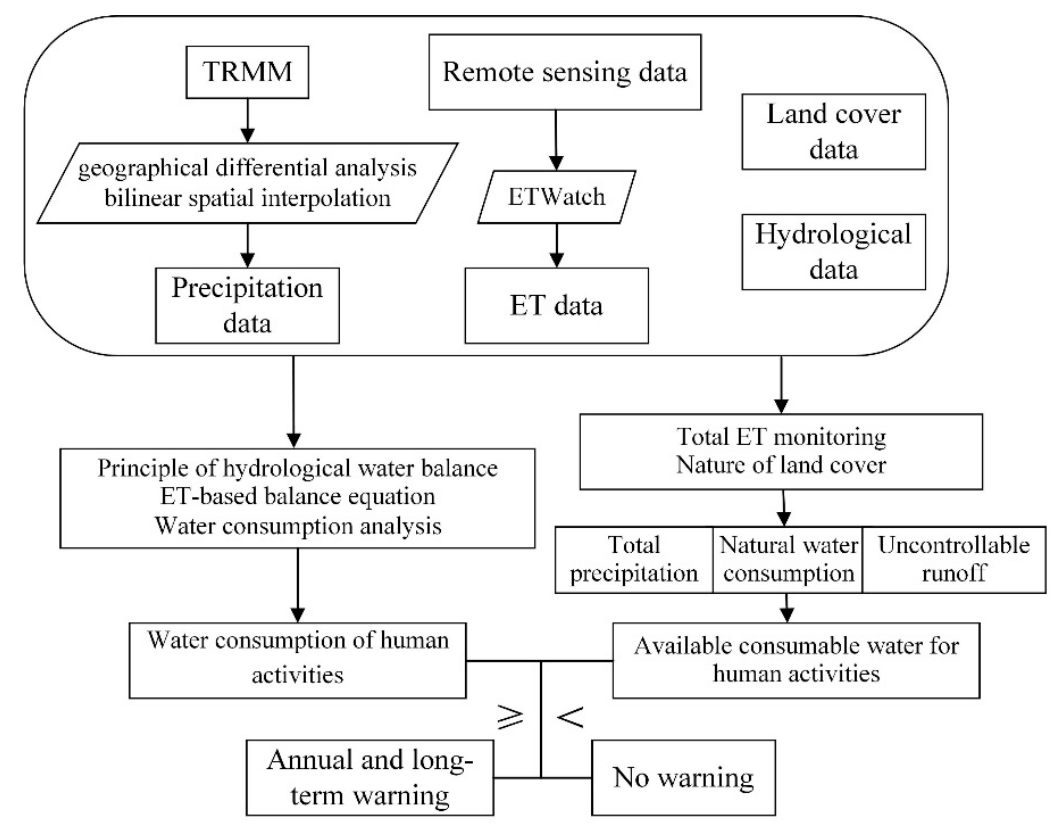

Figure 2. Flowchart of environmental flow regulation and warning.

\subsection{ETWatch}

ETWatch (ETWatch.cn) [52] is an ET monitoring system based on the surface energy balance and Penman-Monteith equation; this system is composed of data acquisition, data preprocessing, ET monitoring, ET application and data management modules [46]. ETWatch uses remote sensing-based monitoring, reanalysis, and site-measured data as inputs, and calculates ET based on the energy balance residual method, which includes net radiation, soil heat flux, aerodynamic roughness, atmospheric boundary layer height, water pressure difference, sensible heat flux, surface impedance, bare soil, water surface, ice and snow ET, and ET fusion modules and is highly robust [48].

\subsection{Water Consumption Analysis}

The traditional water balance analysis methods consider the inflow and outflow of water in a given area, as well as the changes in water storage. $\mathrm{Wu}$ [16] proposed a basinlevel water balance analysis method based on water consumption. The results of this analysis can be used to determine whether water consumption in a basin or sub-basin is sustainable, or whether water consumption must be reduced to restore balance.

Water balance can be estimated for a whole basin or a certain area. The ET-based water balance analysis equation is as follows [53]:

$$
\mathrm{P}-\mathrm{ET}-\mathrm{O}+\mathrm{I}=\Delta \mathrm{gw}+\Delta \mathrm{s}
$$

where $\mathrm{P}$ is the precipitation; ET is the total water consumed (water consumed by evaporation and transpiration); I is the regional surface water inflow; $\mathrm{O}$ is the surface water outflow (I and $\mathrm{O}$ may include interbasin transfer); $\Delta \mathrm{gw}$ is the change in groundwater and soil water storage during a certain period; $\Delta s$ is the change in surface water storage. When groundwater is not over-drafted, $\Delta \mathrm{gw}$ is zero. Because soil water storage is generally assumed to not change over an annual cycle, any change in regional water storage is 
considered to be mainly the result of a change in groundwater storage. Precipitation data (P) can be measured at observation stations or using remote sensing, while inflow and outflow data are measured at major control points and river sections.

For a closed basin, the water balance equation is as follows:

$$
\mathrm{P}+\mathrm{I}=\mathrm{R}+\mathrm{ET}+\Delta \mathrm{W}
$$

where I is expressed as the inflow of water into the basin, including the inflow of surface water and groundwater and the amount of water transferred across basins, and $\mathrm{R}$ represents the amount of water flowing out of the basin. The balance of water resources in a river basin is required to keep the water balance of a river basin equal within a certain period of time. If the sustainable use of water resources is to ensure sustainable economic and social development, the sum of the ET and outbound water in a basin must be equal to the sum of the precipitation and inbound water in the basin.

The most direct application of basin water balance analysis is to calculate the area/basin storage [53]. Generally, soil storage remains unchanged with an annual cycle, and the regional storage variable $\Delta \mathrm{W}$ is equivalent to the groundwater storage variable. Therefore, this method can determine whether there is overexploitation of groundwater in an area, enabling the management of groundwater overexploitation. Precipitation and streamflow data can be obtained from observation station data, and the key to determining the water consumption balance is the calculation of the total regional water consumption.

According to the difference in energy created by the process of water converting from a liquid to a gas, the TWC can be expressed as the sum of three terms, as follows:

$$
\mathrm{ET}_{\mathrm{h}}=\mathrm{ET}_{\mathrm{sol}}+\mathrm{Q}_{\mathrm{m}}+\mathrm{Qb}_{\mathrm{b}}
$$

where $\mathrm{ET}_{\text {sol }}$ is regional ET, which is the evaporation caused by solar energy and can be estimated by remote sensing. This variable includes not only the ET process occurring on the ground in the natural state, e.g., evaporation from croplands, forests, water surfaces, and bare ground but also, a series of evaporation events during and after human disturbances related to production (industry and agriculture) and domestic water use. Water consumption is also caused by the consumption of mineral energy and biological energy in a basin. The evaporation of water caused by the burning of oil and coal is the water consumption caused by mineral energy use, and this type of water consumption is considered mineral energy water consumption $\left(Q_{m}\right)$. The energy source for human or animal perspiration is the biological energy stored in the body. Water consumption due to the loss of biological energy is called bioenergy water consumption $\left(\mathrm{Q}_{\mathrm{b}}\right)$.

\subsection{Environmental Flows Early Warning}

\subsubsection{Natural Evapotranspiration}

Natural ET $\left(\mathrm{ET}_{\mathrm{n}}\right)$ is uncontrollable ET caused by natural characteristics such as climate, soil, and terrain [54]. This method of combining complete ET monitoring and land cover data relies on remote sensing-based ET data and ChinaCover data. Through the classification of the first class of ChinaCover data, the NWC within the basin was calculated as follows:

$$
\mathrm{ET}_{\mathrm{n}}=\mathrm{ET}_{\text {for }}+\mathrm{ET}_{\text {gra }}+\mathrm{ET}_{\text {wet }}+\mathrm{ET}_{\text {fal }}+\mathrm{ET}_{\text {urb }}+\mathrm{ET}_{\text {bar }}
$$

where $\mathrm{ET}_{\mathrm{n}}$ represents the total NWC of the basin; $\mathrm{ET}_{\text {for }}$ is the NWC from natural forests; $\mathrm{ET}_{\text {gra }}$ is the NWC of natural grasslands; $\mathrm{ET}_{\text {wet }}$ is the NWC of natural wetlands and surface water; $\mathrm{ET}_{\mathrm{fal}}$ is the NWC from croplands, assuming no crops for a whole year; $\mathrm{ET}_{\mathrm{urb}}$ is the NWC from urban environments, including precipitation evaporation from impervious surfaces and the loss of precipitation to artificial features; and $\mathrm{ET}_{\mathrm{bar}}$ is the NWC of bare lands, such as bare rock, bare soil, desert, and ice [55]. 


\subsubsection{Available Consumable Water for Human Activities}

According to its definition, the water consumption in a basin includes the ACW for human activities, $\mathrm{ET}_{\mathrm{n}}$ and outflow; hence, the equation for $\mathrm{ACW}$ is as follows:

$$
\mathrm{ACW}=\mathrm{P}-\mathrm{ET}_{\mathrm{n}}-\mathrm{Q}
$$

where $\mathrm{P}$ is precipitation in the basin and $\mathrm{ET}_{\mathrm{n}}$ is the water consumed purely by the natural ecosystem, assuming no intervention by human activities (see Section 3.3.1). $Q$ is the uncontrollable outflow and represents the water resources that cannot be used under the current conditions of water conservancy projects, such as, uninterrupted floods and outflows not available due to their geographic location [22]. For a closed basin, $Q=0$; for sub-basin, $Q$ is the actual outflow.

The outflow of the control section includes uncontrollable outflow and ecological flow, as follows:

$$
\mathrm{Q}=\mathrm{Q}_{\mathrm{f}}+\mathrm{Q}_{\mathrm{e}}
$$

where $Q_{f}$ is the uncontrollable outflow and $Q_{e}$ is the ecological flow, that is, except for excessive floods, the discharge outflow determined according to design.

\subsubsection{Environmental Flows Early Warning Method}

The TWC of a basin can be divided into $\mathrm{ET}_{\mathrm{n}}$ and $\mathrm{ET}_{\mathrm{h}}$, and the equation for TWC is as follows:

$$
\mathrm{TWC}=\mathrm{ET}_{\mathrm{n}}+\mathrm{ET}_{\mathrm{h}}
$$

where $\mathrm{ET}$ is the total $\mathrm{ET} ; \mathrm{ET}_{\mathrm{n}}$ is the natural $\mathrm{ET}$ (see Section 3.3.1); and $\mathrm{ET}_{\mathrm{h}}$ is the increased water consumption in the basin due to human activities, indicating the actual human water consumption [20,56-60]. $\mathrm{ET}_{\mathrm{h}}$ is divided into [53]: (i) water consumption due to irrigation and solar radiation in croplands and green space in urban areas, (ii) water consumption due to the burning of fossil fuels during industrial production, and (iii) water consumption due to the maintenance of human and animal physiological functions, such as perspiration.

Based on the analysis of the water balance in basins, an early warning method for environmental flow issues was constructed. When the upstream water consumption related to human activities $\left(\mathrm{ET}_{\mathrm{h}}\right)$ is greater than the $\mathrm{ACW}$, the environmental flows will be in a state of insufficiency, and the percentage of excess can be interpreted to determine to different warning levels. The warning levels are calculated as follows:

$$
\left\{\begin{array}{c}
\mathrm{ET}_{\mathrm{h}} \geq \mathrm{ACW} \text {, annual and long - term warning } \\
\mathrm{ET}_{\mathrm{h}}<\mathrm{ACW}, \text { no warning }
\end{array}\right.
$$

Early warnings include long-term warnings and annual warnings; the former uses averaged data from several years for analysis, and the latter uses data from a certain year for analysis. When the actual water consumption is close to the target water consumption or there is a trend indicating further reduction, an early warning should be issued immediately, and the reasons for the warning can be further analyzed.

\section{Results}

\subsection{Water Consumption Balance in the Yongding River Basin}

The YD River Basin covers an area of $4.7 \times 10^{4} \mathrm{~km}^{2}$, with a remaining water volume of $2.3 \times 10^{9} \mathrm{~m}^{3}$. Although the water resources are in a state of surplus, groundwater is seriously overexploited, so we focused on infrastructure construction. To reduce the extraction of groundwater, surface water should be used for irrigation. Comprehensive agricultural water-saving measures are continuously being developed to gradually restore the water level. To understand the changes in the annual water consumption trend, ensure a long-term dynamic balance, reduce groundwater overexploitation, and sustainably use water resources, analysis of the annual water consumption balance should be carried out. 
Based on the analysis of remote sensing-based data and statistical precipitation and streamflow data, using the methods described above (see Section 3.2), the water consumption balance of the YD River Basin from 2001 to 2014 is shown in Table 1. The results show that the mean precipitation was $17.90 \times 10^{9} \mathrm{~m}^{3}$ and that the mean water consumption was $19.42 \times 10^{9} \mathrm{~m}^{3}$, indicating that the basin water budget was greatly unbalanced and that the basin was water deficient. The mean storage volume $(\Delta \mathrm{W})$ was $-1.84 \times 10^{9} \mathrm{~m}^{3}$. The groundwater supply in the YD River Basin from 2001 to 2014 was $1.29 \times 10^{9} \mathrm{~m}^{3}$. The results of the water resource evaluation for the Haihe River Basin indicate that the shallow groundwater in this area was exploited at a rate of $1.37 \times 10^{9} \mathrm{~m}^{3}$. From the perspective of the overall water consumption balance, the overexploitation of the water resources was not serious. However, due to the imbalance caused by mining and water utilization, there are serious problems associated with the overexploitation of water resources in cities and the surrounding areas. The groundwater level of the basin continuously lowered, and the rate of decline increased over time. The development and utilization of water resources in the river basin has been unsustainable.

Table 1. Water consumption balance in the YD River Basin from 2001 to $2014\left(10^{9} \mathrm{~m}^{3}\right)$.

\begin{tabular}{|c|c|c|c|c|c|c|c|c|c|c|}
\hline \multirow{3}{*}{ Year } & \multirow{3}{*}{$\mathbf{P}$} & \multirow{3}{*}{ Inflow } & \multicolumn{6}{|c|}{ Actual Water Consumption } & \multirow{3}{*}{ Outflow } & \multirow{3}{*}{$\Delta W$} \\
\hline & & & \multicolumn{3}{|c|}{ Remote Sensing-Based ET } & \multirow{2}{*}{$\mathbf{E T}_{\mathbf{i}}$} & \multirow{2}{*}{$\mathrm{ET}_{1}$} & \multirow{2}{*}{ Total } & & \\
\hline & & & $\mathrm{ET}_{\mathrm{n}}$ & $\mathrm{ET}_{\mathrm{hf}}$ & $\mathrm{ET}_{\text {res }}$ & & & & & \\
\hline 2001 & 15.12 & 0.00 & 15.53 & 2.96 & 0.18 & 0.39 & 0.21 & 19.27 & 0.00 & -4.15 \\
\hline 2002 & 16.61 & 0.00 & 13.15 & 2.65 & 0.22 & 0.40 & 0.20 & 16.62 & 0.36 & -0.37 \\
\hline 2003 & 20.33 & 0.00 & 19.45 & 4.61 & 0.28 & 0.39 & 0.20 & 24.93 & 0.36 & -4.96 \\
\hline 2004 & 19.93 & 0.00 & 15.04 & 2.84 & 0.24 & 0.38 & 0.20 & 18.70 & 0.36 & 0.87 \\
\hline 2005 & 16.34 & 0.00 & 13.32 & 2.07 & 0.22 & 0.41 & 0.22 & 16.24 & 0.36 & -0.26 \\
\hline 2006 & 15.38 & 0.00 & 14.85 & 2.54 & 0.24 & 0.42 & 0.21 & 18.26 & 0.36 & -3.24 \\
\hline 2007 & 17.66 & 0.00 & 15.71 & 2.93 & 0.26 & 0.40 & 0.20 & 19.50 & 0.36 & -2.20 \\
\hline 2008 & 20.02 & 0.00 & 15.45 & 2.74 & 0.29 & 0.34 & 0.21 & 19.03 & 0.36 & 0.63 \\
\hline 2009 & 14.24 & 0.00 & 15.10 & 3.10 & 0.28 & 0.32 & 0.22 & 19.02 & 0.36 & -5.14 \\
\hline 2010 & 20.63 & 0.00 & 16.44 & 2.37 & 0.25 & 0.37 & 0.23 & 19.66 & 0.36 & 0.61 \\
\hline 2011 & 15.77 & 0.02 & 16.54 & 3.39 & 0.29 & 0.34 & 0.24 & 20.80 & 0.36 & -5.37 \\
\hline 2012 & 20.84 & 0.07 & 15.98 & 2.80 & 0.28 & 0.39 & 0.27 & 19.72 & 0.36 & 0.83 \\
\hline 2013 & 20.90 & 0.04 & 18.24 & 2.86 & 0.30 & 0.37 & 0.28 & 22.05 & 0.36 & -1.47 \\
\hline 2014 & 16.88 & 0.07 & 14.97 & 2.22 & 0.28 & 0.34 & 0.28 & 18.09 & 0.36 & -1.50 \\
\hline Avg. & 17.90 & 0.01 & 15.70 & 2.86 & 0.26 & 0.37 & 0.23 & 19.42 & 0.33 & -1.84 \\
\hline
\end{tabular}

Note-P: precipitation; $\mathrm{ET}_{\mathrm{n}}$ : natural $\mathrm{ET} ; \mathrm{ET}_{\mathrm{hf}}$ : $\mathrm{ET}$ from human activities in cropland; $\mathrm{ET}_{\text {res }}$ : $\mathrm{ET}_{\text {from residential }}$ activities; $\mathrm{ET}_{\mathrm{i}}$ : $\mathrm{ET}$ from industrial water; $\mathrm{ET}_{1}$ : $\mathrm{ET}$ from urban environments; $\Delta \mathrm{W}$ : storage variable.

The interannual variation in basin storage fluctuated greatly from 2001 to 2014. Although basin storage increased slightly in some years, it could not compensate for the extremely significant water resource deficit in the basin during 2001-2002. The continuous drought in 2006-2007 caused the storage in the basin area continuously decrease. According to the water consumption balance method, which mainly uses precipitation data, ET data, domestic water consumption data estimated using population and industrial output values, and flow data at the outlet of the river basin rather than groundwater observation data, the annual mean storage volume decreased by $9.53 \times 10^{9} \mathrm{~m}^{3}$ from 2002 to 2008 .

As shown in Table 1, the water consumption in the basin was dominated by solar energy, accounting for $98.2 \%$. Industrial, human and domestic factors accounted for a very low proportion $(1.8 \%$ ) of the TWC. NWC and human activities accounted for $80.8 \%$ and $19.2 \%$ of the total water consumption, respectively, indicating that most of the precipitation in the basin is consumed by natural systems such as forests, grasslands and wetlands. Among human activities, croplands were the dominant driver of water consumption. The mean cropland water consumption from 2001 to 2014 was $2.86 \times 10^{9} \mathrm{~m}^{3}$, accounting for $76.9 \%$. There are two aspects of these results that need to be emphasized: on the one hand, the water resources consumed by human activities accounted for only $20.8 \%$ of the total 
precipitation, most of which was consumed naturally; on the other hand, agricultural water consumption accounted for as much as $83.3 \%$ of the total precipitation consumed by human activities, which is far higher than commonly thought.

\subsection{Environmental Flows Early Warning}

\subsubsection{Water Consumption Analysis in the Yongding River Basin}

Cropland water consumption is controlled by natural and human activities, both of which are important causes of water resource problems in the YD River Basin. Table 2 shows that the total cropland water consumption from 2001 to 2018 was $6.53 \times 10^{9} \mathrm{~m}^{3}$. The NWC in croplands was $5.13 \times 10^{9} \mathrm{~m}^{3}$, and the water consumption associated with human activities in croplands, that is, the difference between the total and the NWC of croplands, was $1.41 \times 10^{9} \mathrm{~m}^{3}$. The new precipitation consumption associated with crop planting is the difference between the total consumption and irrigation water consumption of the crops. The results show that from 2001 to $2018,78.4 \%$ of the cropland water consumption in the YD River Basin was from natural activities, while $21.6 \%$ was from human activities. NWC by crops is the main driver of increased water consumption, so human activities in farmlands cannot be ignored.

Table 2. Agricultural water consumption in the YD River Basin from 2001 to $2018\left(10^{9} \mathrm{~m}^{3}\right)$.

\begin{tabular}{cccc}
\hline Year & Total Cropland ET & Natural Cropland ET & $\begin{array}{c}\text { Cropland Human } \\
\text { Activity ET }\end{array}$ \\
\hline 2001 & 6.43 & 4.79 & 1.64 \\
2002 & 5.79 & 4.46 & 1.33 \\
2003 & 8.11 & 4.94 & 3.17 \\
2004 & 6.41 & 4.94 & 1.47 \\
2005 & 5.53 & 4.72 & 0.81 \\
2006 & 6.24 & 4.93 & 1.31 \\
2007 & 6.62 & 4.97 & 1.65 \\
2008 & 6.47 & 5.01 & 1.45 \\
2009 & 6.60 & 4.67 & 1.93 \\
2010 & 6.40 & 5.31 & 1.08 \\
2011 & 7.02 & 4.99 & 2.03 \\
2012 & 6.87 & 5.35 & 1.52 \\
2013 & 6.86 & 5.24 & 1.62 \\
2014 & 6.16 & 5.17 & 1.00 \\
2015 & 6.48 & 5.68 & 0.81 \\
2016 & 6.54 & 5.81 & 0.73 \\
2017 & 6.68 & 5.92 & 0.76 \\
2018 & 6.41 & 5.37 & 1.05 \\
Average & 6.53 & 5.13 & 1.41 \\
percentage & $100 \%$ & $78.4 \%$ & $21.6 \%$ \\
\hline
\end{tabular}

Tables 3 and 4 show that from 2001 to 2018, in the UCTRYDR and CTRYDRSD, the mean precipitations were $7.23 \times 10^{9} \mathrm{~m}^{3}$ and $11.41 \times 10^{9} \mathrm{~m}^{3}$, and the NWCs were $5.17 \times 10^{9} \mathrm{~m}^{3}$ and $9.22 \times 10^{9} \mathrm{~m}^{3}$, accounting for $72.3 \%$ and $81.72 \%$ of the average annual precipitation, respectively; these findings indicate that most of the precipitation was eventually consumed by natural and artificial features. The uncontrollable outflows were $0.15 \times 10^{9} \mathrm{~m}^{3}$ and $0.21 \times 10^{9} \mathrm{~m}^{3}$ in the UCTRYDR and CTRYDRSD, respectively. The amounts of ACW for human activities were $2.06 \times 10^{9} \mathrm{~m}^{3}$ and $2.20 \times 10^{9} \mathrm{~m}^{3}$ in the UCTRYDR and CTRYDRSD, accounting for $27.7 \%$ and $18.3 \%$ of the average annual precipitation, respectively. However, the interannual variation was great; for example, $0.93 \times 10^{9} \mathrm{~m}^{3}$ and $0.36 \times 10^{9} \mathrm{~m}^{3}$ in 2001 and $2.83 \times 10^{9} \mathrm{~m}^{3}$ and $3.61 \times 10^{9} \mathrm{~m}^{3}$ in 2004 in the UCTRYDR and CTRYDRSD, respectively. 
Table 3. Precipitation, natural ET, ACW, and outflow from the UCTRYDR from 2001 to $2018\left(10^{9} \mathrm{~m}^{3}\right)$.

\begin{tabular}{cccccccccccccccccccccc}
\hline Year & $\mathbf{2 0 0 1}$ & $\mathbf{2 0 0 2}$ & $\mathbf{2 0 0 3}$ & $\mathbf{2 0 0 4}$ & $\mathbf{2 0 0 5}$ & $\mathbf{2 0 0 6}$ & $\mathbf{2 0 0 7}$ & $\mathbf{2 0 0 8}$ & $\mathbf{2 0 0 9}$ & $\mathbf{2 0 1 0}$ & $\mathbf{2 0 1 1}$ & $\mathbf{2 0 1 2}$ & $\mathbf{2 0 1 3}$ & $\mathbf{2 0 1 4}$ & $\mathbf{2 0 1 5}$ & $\mathbf{2 0 1 6}$ & $\mathbf{2 0 1 7}$ & $\mathbf{2 0 1 8}$ & Avg. \\
\hline $\mathrm{P}$ & & 5.88 & 6.77 & 7.73 & 7.51 & 6.24 & 5.96 & 6.72 & 7.64 & 5.23 & 7.67 & 6.41 & 8.45 & 8.55 & 6.45 & 7.36 & 8.43 & 8.08 & 9.12 & 7.23 \\
\hline & $\mathrm{ET}_{\text {for }}$ & 0.35 & 0.30 & 0.45 & 0.37 & 0.31 & 0.39 & 0.45 & 0.62 & 0.58 & 0.77 & 0.70 & 0.64 & 0.94 & 0.78 & 0.86 & 0.92 & 0.94 & 0.78 & 0.62 \\
& $\mathrm{ET}_{\text {gra }}$ & 2.04 & 1.92 & 2.68 & 1.80 & 1.50 & 1.81 & 2.13 & 1.63 & 1.60 & 1.78 & 1.77 & 1.63 & 2.26 & 1.88 & 2.10 & 2.21 & 2.26 & 1.86 & 1.94 \\
Natural & $\mathrm{ET}_{\text {wet }}$ & 0.01 & 0.01 & 0.01 & 0.01 & 0.01 & 0.01 & 0.01 & 0.03 & 0.03 & 0.02 & 0.03 & 0.03 & 0.04 & 0.04 & 0.04 & 0.04 & 0.04 & 0.04 & 0.03 \\
$\mathrm{ET}$ & $\mathrm{ET}_{\text {fal }}$ & 2.33 & 2.07 & 2.22 & 2.24 & 2.04 & 2.23 & 2.28 & 2.36 & 2.12 & 2.51 & 2.40 & 2.53 & 2.68 & 2.18 & 2.41 & 2.50 & 2.57 & 2.29 & 2.33 \\
& $\mathrm{ET}_{\text {urb }}$ & 0.06 & 0.07 & 0.08 & 0.08 & 0.07 & 0.06 & 0.08 & 0.10 & 0.07 & 0.10 & 0.08 & 0.12 & 0.10 & 0.10 & 0.10 & 0.10 & 0.10 & 0.10 & 0.09 \\
& $\mathrm{ET}_{\text {bar }}$ & 0.15 & 0.17 & 0.22 & 0.18 & 0.14 & 0.18 & 0.19 & 0.18 & 0.19 & 0.17 & 0.20 & 0.20 & 0.15 & 0.14 & 0.14 & 0.15 & 0.15 & 0.14 & 0.17 \\
& Total & 4.95 & 4.54 & 5.66 & 4.69 & 4.08 & 4.69 & 5.12 & 4.91 & 4.59 & 5.36 & 5.18 & 5.14 & 6.17 & 5.12 & 5.65 & 5.92 & 6.06 & 5.21 & 5.17 \\
\hline Total/P (\%) & 84.18 & 67.06 & 73.22 & 62.45 & 65.38 & 78.69 & 76.19 & 64.27 & 87.76 & 69.88 & 80.81 & 60.83 & 72.16 & 79.38 & 76.77 & 70.23 & 75.00 & 57.1 & 72.30 \\
Outflow & 0.15 & 0.15 & 0.15 & 0.15 & 0.15 & 0.15 & 0.15 & 0.15 & 0.15 & 0.15 & 0.15 & 0.15 & 0.15 & 0.15 & 0.15 & 0.15 & 0.15 & 0.15 & 0.15 \\
ACW & 0.93 & 2.23 & 2.07 & 2.83 & 2.16 & 1.27 & 1.60 & 2.72 & 0.64 & 2.31 & 1.24 & 3.31 & 2.38 & 1.33 & 1.70 & 2.50 & 2.01 & 3.91 & 2.06 \\
ACW/P (\%) & 15.86 & 32.87 & 26.75 & 37.66 & 34.67 & 21.38 & 23.78 & 35.66 & 12.20 & 30.12 & 19.31 & 39.14 & 27.84 & 20.59 & 23.11 & 29.71 & 24.86 & 42.8 & 27.68 \\
\hline
\end{tabular}

Note-P: precipitation; $\mathrm{ET}_{\text {for }}$ : NWC by natural forests; $\mathrm{ET}_{\text {gra }}$ : NWC by natural grasslands; $\mathrm{ET}_{\text {wet }}$ : NWC by natural wetlands and surface water; $\mathrm{ET}_{\text {fal }}:$ NWC by croplands; $\mathrm{ET}_{\text {urb }}$ : NWC by urban environments; $\mathrm{ET}_{\text {bar }}: \mathrm{NWC}$ by bare lands.

Table 4. Precipitation, natural ET, ACW, and outflow from the CTRYDRSD from 2001 to $2018\left(10^{9} \mathrm{~m}^{3}\right)$.

\begin{tabular}{ccccccccccccccccccccc}
\hline Year & $\mathbf{2 0 0 1}$ & $\mathbf{2 0 0 2}$ & $\mathbf{2 0 0 3}$ & $\mathbf{2 0 0 4}$ & $\mathbf{2 0 0 5}$ & $\mathbf{2 0 0 6}$ & $\mathbf{2 0 0 7}$ & $\mathbf{2 0 0 8}$ & $\mathbf{2 0 0 9}$ & $\mathbf{2 0 1 0}$ & $\mathbf{2 0 1 1}$ & $\mathbf{2 0 1 2}$ & $\mathbf{2 0 1 3}$ & $\mathbf{2 0 1 4}$ & $\mathbf{2 0 1 5}$ & $\mathbf{2 0 1 6}$ & $\mathbf{2 0 1 7}$ & $\mathbf{2 0 1 8}$ & Avg. \\
\hline $\mathrm{P}$ & & 9.24 & 9.84 & 12.60 & 12.42 & 10.09 & 9.42 & 10.94 & 12.38 & 9.01 & 12.96 & 9.36 & 12.39 & 12.35 & 10.43 & 12.71 & 14.85 & 12.82 & 11.6 & 11.41 \\
\hline & $\mathrm{ET}_{\text {for }}$ & 3.01 & 2.12 & 3.51 & 2.92 & 2.66 & 2.85 & 2.85 & 3.05 & 2.74 & 3.58 & 3.13 & 3.12 & 3.53 & 3.06 & 3.23 & 3.45 & 3.58 & 3.12 & 3.08 \\
& $\mathrm{ET}_{\text {gra }}$ & 3.28 & 2.57 & 4.10 & 3.05 & 2.90 & 3.06 & 3.17 & 3.14 & 3.03 & 3.41 & 3.36 & 3.16 & 3.53 & 2.87 & 3.13 & 3.25 & 3.38 & 2.85 & 3.18 \\
Natural & $\mathrm{ET}_{\text {wet }}$ & 0.06 & 0.05 & 0.07 & 0.05 & 0.04 & 0.05 & 0.05 & 0.05 & 0.04 & 0.04 & 0.05 & 0.05 & 0.08 & 0.07 & 0.07 & 0.07 & 0.08 & 0.07 & 0.06 \\
ET & $\mathrm{ET}_{\text {fal }}$ & 2.46 & 2.40 & 2.72 & 2.69 & 2.67 & 2.70 & 2.69 & 2.65 & 2.55 & 2.81 & 2.59 & 2.82 & 2.55 & 2.98 & 3.27 & 3.31 & 3.35 & 3.08 & 2.79 \\
& $\mathrm{ET}_{\text {urb }}$ & 0.06 & 0.07 & 0.09 & 0.09 & 0.08 & 0.07 & 0.08 & 0.11 & 0.08 & 0.12 & 0.09 & 0.11 & 0.12 & 0.11 & 0.11 & 0.11 & 0.11 & 0.11 & 0.09 \\
& $\mathrm{ET}_{\text {bar }}$ & 0.00 & 0.00 & 0.00 & 0.01 & 0.00 & 0.01 & 0.01 & 0.01 & 0.01 & 0.01 & 0.01 & 0.01 & 0.01 & 0.01 & 0.01 & 0.01 & 0.01 & 0.01 & 0.01 \\
& Total & 8.88 & 7.20 & 10.50 & 8.81 & 8.35 & 8.74 & 8.84 & 9.01 & 8.45 & 9.97 & 9.22 & 9.27 & 9.82 & 9.10 & 9.82 & 10.20 & 10.50 & 9.23 & 9.22 \\
\hline Total/P (\%) & 84.18 & 96.10 & 73.17 & 83.33 & 70.93 & 82.76 & 92.78 & 80.80 & 72.78 & 93.78 & 76.93 & 98.50 & 74.82 & 79.51 & 87.25 & 77.26 & 68.69 & 81.90 & 79.6 \\
Outflow & 0.15 & 0.21 & 0.21 & 0.21 & 0.21 & 0.21 & 0.21 & 0.21 & 0.21 & 0.21 & 0.21 & 0.21 & 0.21 & 0.21 & 0.21 & 0.21 & 0.21 & 0.21 & 0.21 \\
ACW & 0.93 & 0.36 & 2.64 & 2.10 & 3.61 & 1.74 & 0.68 & 2.10 & 3.37 & 0.56 & 2.99 & 0.14 & 3.12 & 2.53 & 1.34 & 2.89 & 4.65 & 2.32 & 2.39 \\
ACW/P (\%) & 15.86 & 3.90 & 26.83 & 16.67 & 29.07 & 17.24 & 7.22 & 19.20 & 27.22 & 6.22 & 23.07 & 1.50 & 25.18 & 20.49 & 12.85 & 22.74 & 31.31 & 18.10 & 20.6 \\
\hline
\end{tabular}

Figure 3 shows that the precipitation and water consumption in the UCTRYDR and CTRYDRSD fluctuated dynamically over the 2001-2018 period. The annual precipitation in each sub-basin also showed obvious changes between wet and dry conditions. The mean amounts of precipitation in the regions were $7.23 \times 10^{9} \mathrm{~m}^{3}$ and $11.41 \times 10^{9} \mathrm{~m}^{3}$, respectively. For the UCTRYDR, the maximum precipitation was observed in $2018\left(9.12 \times 10^{9} \mathrm{~m}^{3}\right)$, and the minimum precipitation was observed in $2009\left(5.23 \times 10^{9} \mathrm{~m}^{3}\right)$; for the CTRYDRSD, the maximum precipitation was observed in $2016\left(14.85 \times 10^{9} \mathrm{~m}^{3}\right)$, and the minimum was observed in $2009\left(9.01 \times 10^{9} \mathrm{~m}^{3}\right)$.

In this study, the study period was divided into three parts: 2001-2006, 2007-2012, and 2013-2018. In the UCTRYDR, the mean annual precipitation was $6.68 \times 10^{9} \mathrm{~m}^{3}$ from 2001 to 2006, $7.02 \times 10^{9} \mathrm{~m}^{3}$ from 2007 to 2012 , and $8.00 \times 10^{9} \mathrm{~m}^{3}$ from 2013 to 2018, with increases of $0.34 \times 10^{9} \mathrm{~m}^{3}$ and $0.98 \times 10^{9} \mathrm{~m}^{3}$ between the periods. There, $\mathrm{ET}_{\mathrm{h}}$ changed dynamically with precipitation, and the ACW was $1.92 \times 10^{9} \mathrm{~m}^{3}$ (2001-2006), $1.97 \times 10^{9} \mathrm{~m}^{3}(2007-2012)$ and $2.31 \times 10^{9} \mathrm{~m}^{3}$ (2013-2018), with increases of $0.05 \times 10^{9} \mathrm{~m}^{3}$ and $0.34 \times 10^{9} \mathrm{~m}^{3}$ between the periods. Compared with the increases in precipitation, the increases in the ACW between the periods were less than $0.29 \times 10^{9} \mathrm{~m}^{3}$ and $0.64 \times 10^{9} \mathrm{~m}^{3}$, indicating that the ACW still followed an increasing trend. 

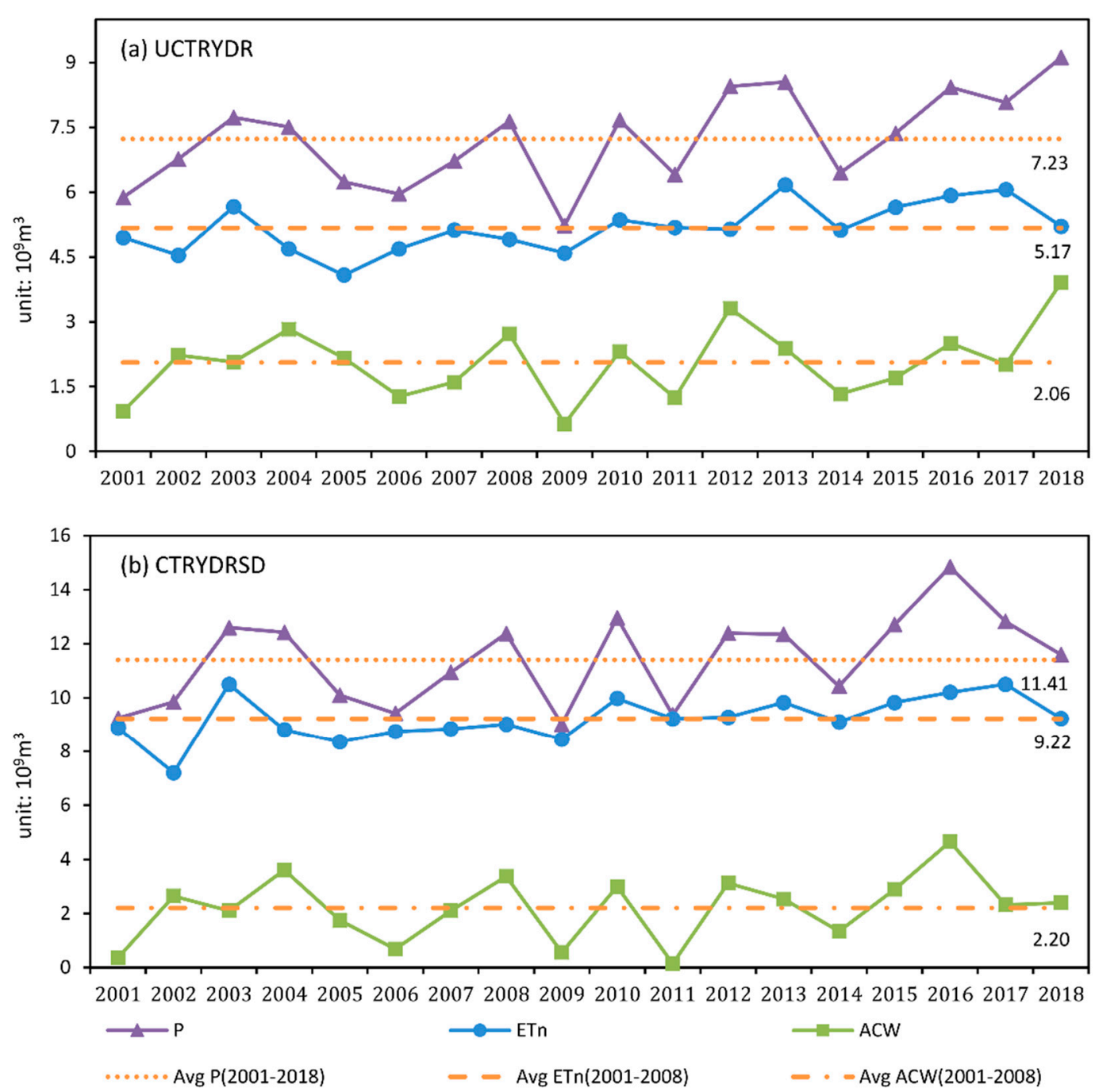

Figure 3. Precipitation, natural ET and ACW development in (a) the UCTRYDR; and (b) the CTRYDRSD from 2001 to 2018.

In the CTRYDRSD, the mean annual precipitation was $10.60 \times 10^{9} \mathrm{~m}^{3}$ for $2001-$ $2006,11.17 \times 10^{9} \mathrm{~m}^{3}$ for 2007-2012 and $12.46 \times 10^{9} \mathrm{~m}^{3}$ for 2013-2018, with increases of $0.57 \times 10^{9} \mathrm{~m}^{3}$ and $1.29 \times 10^{9} \mathrm{~m}^{3}$ between the periods. There, $\mathrm{ET}_{\mathrm{h}}$ changed dynamically with precipitation, and the ACW was $1.86 \times 10^{9} \mathrm{~m}^{3}$ for 2001-2006, $2.05 \times 10^{9} \mathrm{~m}^{3}$ for 20072012 , and $2.69 \times 10^{9} \mathrm{~m}^{3}$ for 2013-2018, with increases of $0.05 \times 10^{9} \mathrm{~m}^{3}$ and $0.34 \times 10^{9} \mathrm{~m}^{3}$ between the periods. Compared with the precipitation, the increases in the ACW were less than $0.19 \times 10^{9} \mathrm{~m}^{3}$ between 2001-2006 and 2007-2012 and $0.64 \times 10^{9} \mathrm{~m}^{3}$ between 2007-2012 and 2013-2018, indicating that the observed amounts of ACW followed an increasing trend.

\subsubsection{Environmental Flows Warning in the Yongding River Basin}

Table 5 shows the $\mathrm{ET}_{\mathrm{h}}$ and ACW results, as well as the average of and differences between them, in the YD River Basin from 2005 to 2014. For the UCTRYDR, $\mathrm{ET}_{\mathrm{h}}$ was $1.39 \times 10^{9} \mathrm{~m}^{3}$, and the ACW was $1.89 \times 10^{9} \mathrm{~m}^{3}$ from 2005 to 2014 . There, $\mathrm{ET}_{\mathrm{h}}$ exceeded the ACW by $57.9 \%$ in 2009; during 2005-2007 and 2012-2014, the $\mathrm{ET}_{\mathrm{h}}$ was close to the target of the ACW and showed a trend of further reduction, by $0.90 \times 10^{9} \mathrm{~m}^{3}$ and $0.74 \times 10^{9} \mathrm{~m}^{3}$, respectively. In particular, the magnitude of reduction was fairly large during 2008-2009 and 2010-2011, at $2.21 \times 10^{9} \mathrm{~m}^{3}$ and $1.47 \times 10^{9} \mathrm{~m}^{3}$, respectively. Hence, the early warning of environmental flow issues should have been carried out in the corresponding years. 
Table 5. $\mathrm{ET}_{\mathrm{h}}$, and the ACW in the UCTRYDR and CTRYDRSD regions from 2005 to $2014\left(10^{9} \mathrm{~m}^{3}\right)$.

\begin{tabular}{ccccccc}
\hline \multirow{2}{*}{ Year } & \multicolumn{2}{c}{ ET $_{\mathbf{h}}$} & \multicolumn{2}{c}{ ACW } & \multicolumn{2}{c}{ ACW-ET $_{\mathbf{h}}$} \\
\cline { 2 - 7 } & UCTRYDR & CTRYDRSD & UCTRYDR & CTRYDRSD & UCTRYDR & CTRYDRSD \\
\hline 2005 & 1.13 & 1.79 & 2.16 & 1.74 & 1.03 & -0.05 \\
2006 & 1.32 & 2.09 & 1.27 & 0.68 & -0.05 & -1.41 \\
2007 & 1.47 & 2.32 & 1.6 & 2.1 & 0.13 & -0.22 \\
2008 & 1.39 & 2.19 & 2.72 & 3.37 & 1.33 & 1.18 \\
2009 & 1.52 & 2.4 & 0.64 & 0.56 & -0.88 & -1.84 \\
2010 & 1.25 & 1.97 & 2.31 & 2.99 & 1.06 & 1.02 \\
2011 & 1.65 & 2.61 & 1.24 & 0.14 & -0.41 & -2.47 \\
2012 & 1.45 & 2.29 & 3.31 & 3.12 & 1.86 & 0.83 \\
2013 & 1.48 & 2.33 & 2.38 & 2.53 & 0.9 & 0.2 \\
2014 & 1.21 & 1.91 & 1.33 & 1.34 & 0.12 & -0.57 \\
Average & 1.39 & 2.19 & 1.89 & 1.85 & 0.51 & -0.33 \\
\hline
\end{tabular}

For the CTRYDRSD, $\mathrm{ET}_{\mathrm{h}}$ was $2.19 \times 10^{9} \mathrm{~m}^{3}$, and the ACW was $1.85 \times 10^{9} \mathrm{~m}^{3}$ from 2005 to 2014. There, $\mathrm{ET}_{\mathrm{h}}$ exceeded the ACW in 2005, 2006, 2007, 2009, 2011 and 2014 (especially in 2009 and 2011); in these years, the amounts of ACW were $0.05 \times 10^{9} \mathrm{~m}^{3}$, $0.14 \times 10^{9} \mathrm{~m}^{3}, 0.22 \times 10^{9} \mathrm{~m}^{3}, 1.84 \times 10^{9} \mathrm{~m}^{3}, 2.47 \times 10^{9} \mathrm{~m}^{3}$ and $1.57 \times 10^{9} \mathrm{~m}^{3}$, respectively. During 2005-2006 and 2012-2014, $\mathrm{ET}_{\mathrm{h}}$ was close to the target of the ACW and showed a trend of further reduction, by $1.58 \times 10^{9} \mathrm{~m}^{3}$ and $1.74 \times 10^{9} \mathrm{~m}^{3}$, respectively. Considering the 10-year average, $\mathrm{ET}_{\mathrm{h}}$ exceeded the amount of $\mathrm{ACW}$, which was $0.33 \times 10^{9} \mathrm{~m}^{3}$. In this case, a long-term warning should have been issued. Notably, all the land cover types except grasslands (i.e., forest, wetland, cropland and urban areas) experienced an increasing trend $[\mathrm{Wu}]$. Therefore, long-term warnings should focus on the impact of ecological restoration, green infrastructure construction and agricultural development on environmental flows.

Table 6 shows that in 2014, the precipitation in both the UCTRYDR and CTRYDRSD regions decreased compared with that in the previous year, with reductions of $2.1 \times 10^{9} \mathrm{~m}^{3}$ and $1.92 \times 10^{9} \mathrm{~m}^{3}$, respectively. Forests and grasslands experienced decreases in precipitation, accounting for $6.72 \%$ and $14.18 \%$, respectively, of the total precipitation. The decreases in the croplands and urban areas accounted for $40.98 \%$ and $1.67 \%$, respectively, of the total precipitation. For UCTRYDR, ET $\mathrm{h}$ was $1.21 \times 10^{9} \mathrm{~m}^{3}$, and the ACW was $1.33 \times 10^{9} \mathrm{~m}^{3}$. Although $\mathrm{ET}_{\mathrm{h}}<\mathrm{ACW}$, this difference decreased compared with the values for the previous year. For the CTRYDRSD, $\mathrm{ET}_{\mathrm{h}}$ was $1.91 \times 10^{9} \mathrm{~m}^{3}$, which exceeded the ACW $\left(1.34 \times 10^{9} \mathrm{~m}^{3}\right)$ by $0.57 \times 10^{9} \mathrm{~m}^{3}$ and also showed a decreasing trend from the previous years; hence, an annual warning should have been issued for water consumption in 2014.

Table 6. $\mathrm{ET}_{\mathrm{h}}$ and ACW for the UCTRYDR and CTRYDRSD regions in $2014\left(10^{9} \mathrm{~m}^{3}\right)$.

\begin{tabular}{ccc}
\hline Sub-Basin & UCTRYDR & CTRYDRSD \\
\hline $\mathrm{ET}_{\mathrm{h}}$ & 1.21 & 1.91 \\
$\mathrm{ACW}$ & 1.33 & 1.34 \\
$\mathrm{ACW}-\mathrm{ET}_{\mathrm{h}}$ & 0.12 & -0.57 \\
\hline
\end{tabular}

\section{Discussion}

\subsection{Water Supply and Water Consumption Analysis}

The use of ET as a metric for water resource management is based on the principles of hydrology and water balance. The whole water cycle is used as the basis for analysis. The target of management is total water vapor flux, which is based on the relationship between the supply and consumption of water resources in a river basin. Limited water consumption is used as the upper limit of resource management, and ET is reduced through measures from perspectives such as engineering, agronomy, management, policy, and biology to save resources, change the current state of groundwater overexploitation in the basin, and gradually realize goals such as the replenishment of groundwater, the 
maintenance of a specific and appropriate ecological base flow, and the fulfillment of requirements of macro and microlevel quota management. An essential part of using ET for water resource management is to implement broader regulations and management of resources than required by traditional water management approaches; ET-based water resource management is also the management of water consumption in the water cycle.

Water consumption management is a complement to, and further development of, water supply management and water demand management [61]. It is a product of technological advancements and a conceptual leap from water resource management. Water consumption management focuses on controlling the consumption of water resources (mainly ET), emphasizing the total control of the target ET, the reduction in water consumption and the increase in water productivity to achieve a sustainable and efficient use of water resources.

Table 7 and Figure 4 show that from 2001 to 2014 in the YD River Basin, the water supply was maintained at approximately $2.0 \times 10^{9} \mathrm{~m}^{3}$. The minimum and maximum water supplies were observed in $2009\left(18.05 \times 10^{9} \mathrm{~m}^{3}\right)$ and $2003\left(21.62 \times 10^{9} \mathrm{~m}^{3}\right)$, respectively. The local surface water supply was related to precipitation and streamflow and was between $5.63 \times 10^{9} \mathrm{~m}^{3}$ and $8.19 \times 10^{9} \mathrm{~m}^{3}$. After the inclusion of the Yellow River water supply from 2011 to 2014, the local surface water supply was maintained at an average of approximately $6.55 \times 10^{9} \mathrm{~m}^{3}$. The groundwater supply was between $12.00 \times 10^{9} \mathrm{~m}^{3}$ and $13.00 \times 10^{9} \mathrm{~m}^{3}$, reaching the highest level in $2010\left(13.84 \times 10^{9} \mathrm{~m}^{3}\right)$ and then experiencing a decreasing trend. With the improvement in the urban wastewater recycling level and the increase in the amount of recycled water used, a decrease in unconventional water use occurred, from $0.06 \times 10^{9} \mathrm{~m}^{3}$ in 2001 to $0.75 \times 10^{9} \mathrm{~m}^{3}$ in 2014 .

Table 7. Water supply and water consumption in the YD River Basin from 2001 to $2014\left(10^{9} \mathrm{~m}^{3}\right)$.

\begin{tabular}{|c|c|c|c|c|c|c|c|c|c|c|c|c|c|}
\hline \multirow{3}{*}{ Year } & \multicolumn{5}{|c|}{ Water Supply } & \multicolumn{8}{|c|}{ Water Consumption } \\
\hline & \multicolumn{2}{|c|}{$\begin{array}{c}\text { Surface } \\
\text { Water }\end{array}$} & \multirow[t]{2}{*}{ GW } & \multirow[t]{2}{*}{ UW } & \multirow[t]{2}{*}{ Tot. } & \multicolumn{2}{|c|}{ Domestic } & \multirow[t]{2}{*}{ IND } & \multicolumn{2}{|c|}{ Agriculture } & \multicolumn{2}{|c|}{ Ecosystem } & \multirow[t]{2}{*}{ Tot. } \\
\hline & Tot. & YW & & & & Tot. & UB & & Tot. & Irr & Tot. & UC & \\
\hline 2001 & 8.19 & 0.00 & 12.15 & 0.06 & 20.40 & 2.10 & 1.26 & 3.90 & 14.38 & 13.23 & 0.02 & 0.00 & 20.40 \\
\hline 2002 & 7.71 & 0.00 & 12.63 & 0.06 & 20.40 & 1.96 & 1.26 & 3.99 & 14.43 & 13.19 & 0.02 & 0.00 & 20.40 \\
\hline 2003 & 7.90 & 0.00 & 13.61 & 0.11 & 21.62 & 1.99 & 1.34 & 3.86 & 15.72 & 14.43 & 0.05 & 0.02 & 21.62 \\
\hline 2004 & 7.34 & 0.00 & 13.37 & 0.09 & 20.79 & 2.04 & 1.35 & 3.79 & 14.89 & 13.72 & 0.07 & 0.04 & 20.79 \\
\hline 2005 & 7.93 & 0.00 & 11.76 & 0.24 & 19.92 & 2.17 & 1.54 & 4.12 & 13.54 & 12.58 & 0.10 & 0.07 & 19.92 \\
\hline 2006 & 6.95 & 0.00 & 12.62 & 0.19 & 19.76 & 2.10 & 1.46 & 4.22 & 13.34 & 12.32 & 0.09 & 0.05 & 19.76 \\
\hline 2007 & 6.68 & 0.00 & 13.03 & 0.22 & 19.93 & 2.01 & 1.39 & 4.02 & 13.80 & 12.82 & 0.10 & 0.06 & 19.93 \\
\hline 2008 & 6.34 & 0.00 & 12.90 & 0.25 & 19.49 & 2.12 & 1.41 & 3.37 & 13.84 & 12.91 & 0.16 & 0.11 & 19.49 \\
\hline 2009 & 5.63 & 0.00 & 12.15 & 0.27 & 18.05 & 2.21 & 1.46 & 3.18 & 12.55 & 11.69 & 0.12 & 0.07 & 18.05 \\
\hline 2010 & 5.87 & 0.00 & 13.84 & 0.40 & 20.10 & 2.25 & 1.46 & 3.71 & 13.77 & 12.93 & 0.37 & 0.33 & 20.10 \\
\hline 2011 & 6.71 & 0.24 & 13.46 & 0.58 & 20.76 & 2.41 & 1.62 & 3.41 & 14.58 & 13.59 & 0.35 & 0.23 & 20.76 \\
\hline 2012 & 6.33 & 0.65 & 13.49 & 0.84 & 20.66 & 2.66 & 1.81 & 3.85 & 13.69 & 12.83 & 0.46 & 0.34 & 20.66 \\
\hline 2013 & 6.45 & 0.41 & 12.42 & 1.39 & 20.25 & 2.79 & 1.91 & 3.66 & 13.21 & 12.41 & 0.59 & 0.39 & 20.25 \\
\hline 2014 & 6.71 & 0.70 & 12.41 & 0.75 & 19.87 & 2.77 & 1.93 & 3.36 & 13.07 & 12.24 & 0.67 & 0.45 & 19.87 \\
\hline Avg & 6.91 & 0.14 & 12.85 & 0.39 & 20.14 & 2.25 & 1.51 & 3.75 & 13.92 & 12.92 & 0.23 & 0.15 & 20.14 \\
\hline
\end{tabular}

Note-YW: inclusion of the Yellow River; GW: groundwater; UW: unconventional water, such as rainwater and recycled water; UB: urban areas; IND: industry; Irr: cropland irrigation; UC: urban ecology. 

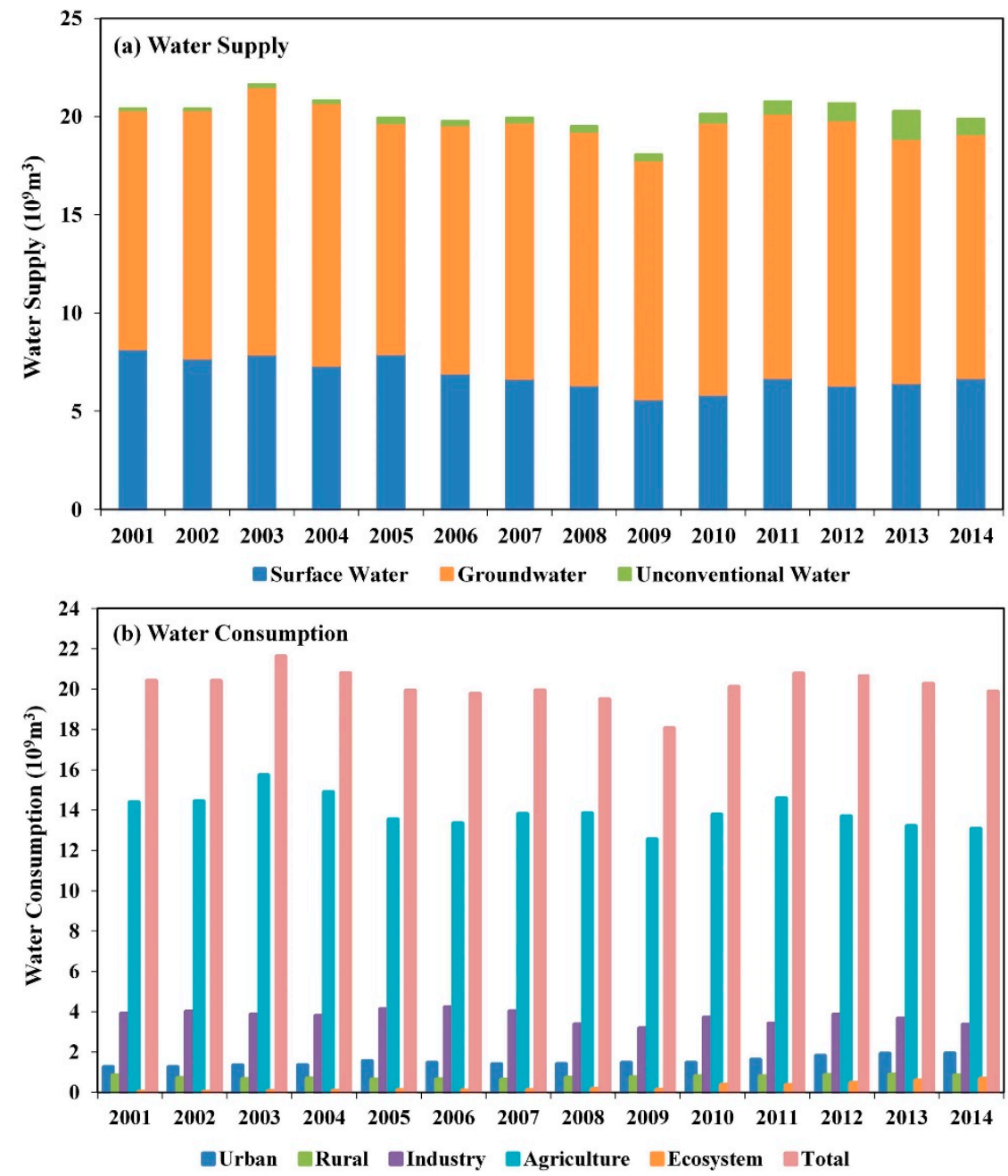

Figure 4. (a) Water supply and (b) water consumption in the YD River Basin from 2001 to 2014.

Figure 4 shows the water consumption in the YD River Basin from 2001 to 2014. There was an upward trend in water consumption in domestic areas and ecosystems and a decrease in water consumption in industrial and agricultural areas. The TWC was maintained at approximately $20.00 \times 10^{9} \mathrm{~m}^{3}$. Agricultural water consumption decreased by $1.31 \times 10^{9} \mathrm{~m}^{3}$. With the increase in water conservation and the adjustment of industrial structures, industrial water consumption decreased by $0.54 \times 10^{9} \mathrm{~m}^{3}$. Regarding domestic water use, water consumption in urban areas increased by $0.67 \times 10^{9} \mathrm{~m}^{3}$, while that in rural areas was maintained from $0.6 \times 10^{9} \mathrm{~m}^{3}$ to $0.89 \times 10^{9} \mathrm{~m}^{3}$. With the increase in recycled water supplied to urban rivers and lakes, the water consumption in ecological environments increased annually, from $0.02 \times 10^{9} \mathrm{~m}^{3}$ to $0.67 \times 10^{9} \mathrm{~m}^{3}$.

Given the importance of the water consumption balance, water resource management approaches should be considered. Based on our study, we present three findings. First, it is necessary to continuously analyze the water consumption balance, reasonably control the water consumption in dry years, and strictly control the water consumption in wet years to ensure that surplus water is recharged to groundwater. In addition, agricultural fallow is beneficial to water shortages at the basin scale, but it was not possible to assess its impact on social security. Improving water productivity will greatly help to achieve efficient water consumption in agriculture. However, the standard for developing water-saving agriculture is not to increase irrigation areas but to reduce agricultural ET and alleviate the downward trend of the groundwater level. Finally, for a long time, water resource management experts have attached great importance to industrial water and domestic water but have ignored the measurement of water consumption. 


\subsection{Available Consumable Water and Early Warning}

An early warning system for environmental flow issues is further developed through the analysis of the water consumption balance. In the water consumption analysis, a method for determining the total amount of water resources in the basin is provided from the perspective of water consumption management and control. The ACW is the upper limit of human water consumption considering human interventions in the basin. Any new human intervention in the natural landscape, such as afforestation, may change this balance; if the natural landscape is stable, then the ACW represents the maximum amount of water that can be consumed by human activities [22]. Early warnings can improve the effect of water consumption management in river basins by tracing the temporal and spatial changes in water consumption. However, regular warning is not very effective in tracking dynamic changes, so early warning can be used to grasp the progress of water resources in a timelier manner and to regulate and control river basin water resource management.

Notably, the ACW is the amount of water that can be consumed by agricultural, industrial or domestic water use. Before water is evaporated, it can be used repeatedly through circulation; the ACW is calculated from precipitation and $\mathrm{ET}_{\mathrm{n}}$, not hydrological data, and is simple and convenient to derive. Rivers correspond to strong human interventions, such as dams, backwaters, and retreats, but these have almost no effect on the estimation of water consumption. The ACW decreases with ecological restoration, which is consistent with the relationship between the ACW and sustainable development. Unlike water withdrawal, water consumption is directly related to the ecological processes in the basin.

When there are upstream increases in water consumption and decreases in precipitation resulting in downstream decreases in water consumption, agricultural and environmental flows will be reduced in upstream areas. Otherwise, there will be a shortage of water resources, and downstream environmental flow consumption cannot be guaranteed. At this time, there is a need for early warnings related to environmental flows. There are many reasons for a shortage of environmental flows, including excessive upstream water consumption, human-made diversion or controlled discharge. However, the main factor leading to the shortage of environmental flows is the overuse of water resources relative to the allowable water consumption. In practice, the cooperation of researchers, technicians, industry management departments and river basin management departments is required to deliver a reliable report, and release early warning information in a timely manner.

\subsection{Limitations and Outlook}

The method proposed in this article involves many types of data, and the use of remote sensing data is key. However, the application of remote sensing in basin management has some limitations: there are few conventional applications, as it is more for emergency use; industry management departments have fewer needs for such an application, which generally require complex processing and debugging. Additionally, remote sensing is widely used in watershed land use classification, while other quantitative remote sensing methods are difficult to promote and apply in watershed management. Data bottlenecks still exist: on the one hand, there is a lack of continuous field observation data to effectively calibrate and verify remote sensing methods or models; on the other hand, the industry application department is still unable to obtain continuous raw spatial and temporal remote sensing data and data analysis products for remote sensing data. With the maturity of remote sensing method and the development of cloud computing technology, we need to further strengthen the study of water consumption estimation methods for human activities in river basins and the driving mechanism of dynamic ET changes due to human activities to further water consumption management, and improve the effect of water consumption management in the river basin. 


\section{Conclusions}

In this study, a method for environmental flow regulation and early warning was proposed, and a case study of the YD River Basin was carried out. The water consumption analysis was based on the water balance relationship. From 2001 to 2014, the mean precipitation was $17.90 \times 10^{9} \mathrm{~m}^{3}$, and the mean water consumption was $19.42 \times 10^{9} \mathrm{~m}^{3}$, indicating that the basin water budget was unbalanced and that there was a general deficiency. Combined with the imbalance between groundwater exploitation and utilization, we concluded that the development and utilization of water resources in the YD River Basin were unsustainable.

The ACW for human activities is based on the water balance equation. The ACW was determined for the UCTRYDR and CTRYDRSD regions from 2001 to 2018. We calculated the difference between the ACW and $\mathrm{ET}_{\mathrm{h}}$ and chose a ten-year period (2005-2014) and a single year (2014) for analysis. The differences in the ACW and $\mathrm{ET}_{\mathrm{h}}$ over the ten-year period were $0.51 \times 10^{9}$ and $-0.33 \times 10^{9} \mathrm{~m}^{3}$, respectively, and both showed a trend of further reduction from 2005 to 2014; similar results were found for 2014. The main conclusion that was drawn from these findings is that long-term and annual early warnings should have been issued.

Further research should consider the potential effects of human activities more carefully, for example, further strengthening the study of estimation methods for water consumption due to human activities in basins and the mechanism driving the dynamic changes in ET due to human activities.

Author Contributions: Conceptualization, Y.L. and B.W.; methodology, Y.L.; data curation, Y.L.; writing—original draft preparation, Y.L.; writing—review and editing, B.W., N.Y., W.Z., H.Z., L.W. All authors have read and agreed to the published version of the manuscript.

Funding: This research was funded by National Natural Scientific Foundations of China, grant number 41991232.

Institutional Review Board Statement: Not applicable.

Informed Consent Statement: Not applicable.

Data Availability Statement: Not applicable.

Acknowledgments: The authors would like to thank the Haihe River Water Conservancy Commission (HWCC, http:/ /hwcc.gov.cn, accessed on 30 June 2020) for providing the hydrological data and streamflow data.

Conflicts of Interest: The authors declare no conflict of interest.

\section{Nomenclature}

$\begin{array}{ll}\text { YD } & \text { Yongding } \\ \text { ET } & \text { Evapotranspiration } \\ \text { ET }_{\mathrm{h}} & \text { Water consumption by human activities } \\ \text { ACW } & \text { Available consumable water } \\ \text { UCTRYDR } & \text { Upstream of the Cetian reservoir of the Yongding River } \\ \text { CTRYDRSD } & \text { Cetian reservoir of the Yongding River to Sanjiadian } \\ \text { TRMM } & \text { Tropical Rainfall Measuring Mission } \\ \mathrm{HWCC} & \text { Haihe River Water Conservancy Commission } \\ \mathrm{P} & \text { Precipitation } \\ \mathrm{O} & \text { Surface water outflow } \\ \mathrm{I} & \text { Regional surface water inflow } \\ \Delta \mathrm{gw} & \text { The change in groundwater and soil water storage } \\ \Delta \mathrm{s} & \text { The change in surface water storage } \\ \mathrm{R} & \text { The amount of outbound water flowing out of the basin }\end{array}$




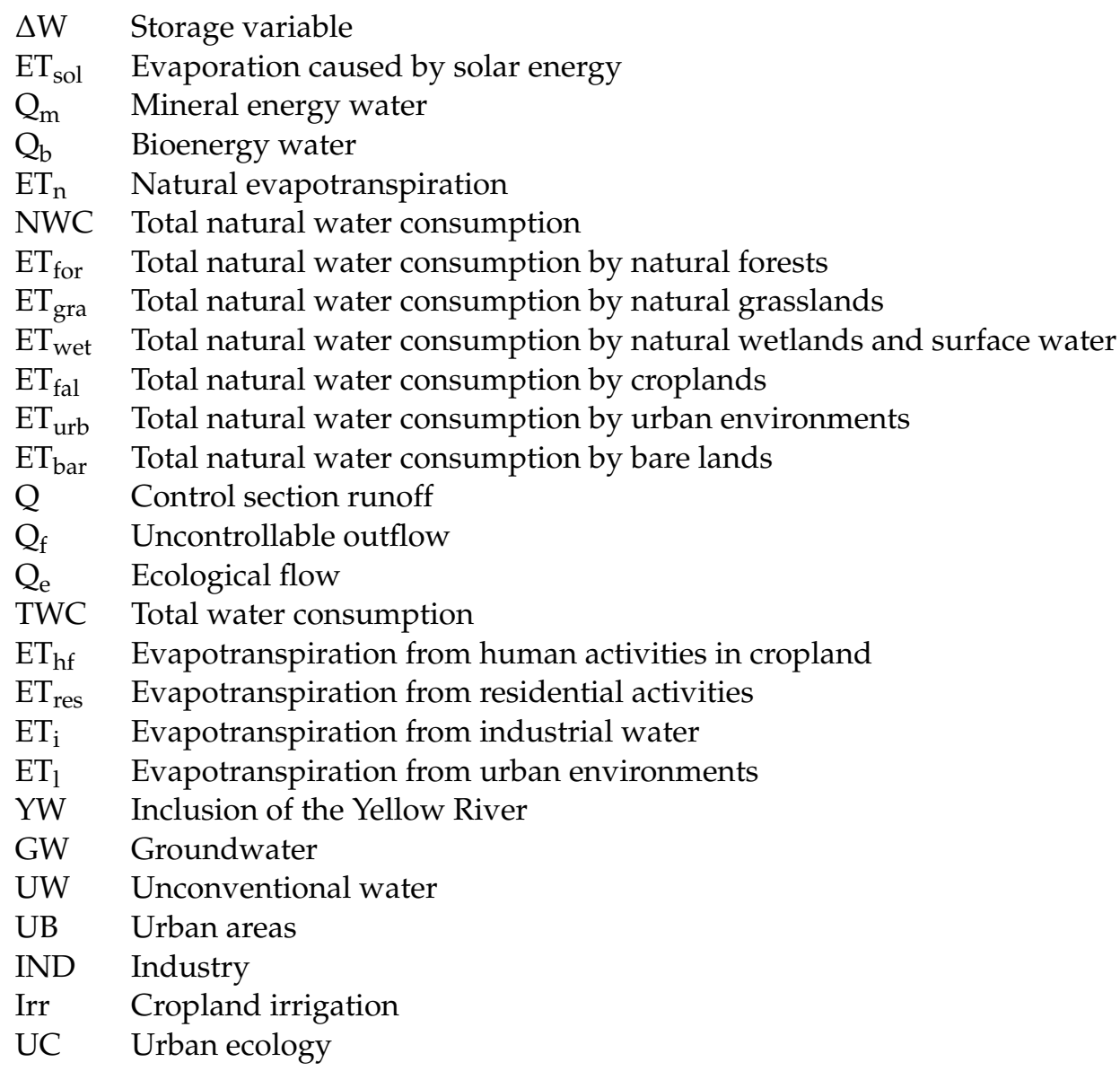

\section{References}

1. Downs, P.W.; Gregory, K.J.; Brookes, A. How integrated is river basin management? Environ. Manag. 1991, 15, 299-309. [CrossRef]

2. Asmamaw, D.K. A critical review of integrated river basin management in the upper Blue Nile river basin: The case of Ethiopia. Int. J. River Basin Manag. 2015, 13, 429-442. [CrossRef]

3. Dworsky, L.B.; Allee, D.J.; North, R.M. Water resources planning and management in the United States federal system: Long term assessment and intergovernmental issues. Nat. Resour. J. 1991, 31, 475.

4. Cheng, G.; Li, X.; Zhao, W.; Xu, Z.; Feng, Q.; Xiao, S.; Xiao, H. Integrated study of the water-ecosystem-economy in the Heihe River Basin. Natl. Sci. Rev. 2014, 1, 413-428. [CrossRef]

5. Pang, A.; Li, C.; Sun, T.; Yang, W.; Yang, Z. Trade-Off Analysis to Determine Environmental Flows in a Highly Regulated Watershed. Sci. Rep. 2018, 8, 14130. [CrossRef] [PubMed]

6. McCartney, M.P.; Shiferaw, A.; Seleshi, Y. Estimating environmental flow requirements downstream of the Chara Chara weir on the Blue Nile River. Hydrol. Process. 2009, 23, 3751-3758. [CrossRef]

7. Gerten, D.; Hoff, H.; Rockström, J.; Jägermeyr, J.; Kummu, M.; Pastor, A.V. Towards a revised planetary boundary for consumptive freshwater use: Role of environmental flow requirements. Curr. Opin. Environ. Sustain. 2013, 5, 551-558. [CrossRef]

8. Barrow, C.J. River basin development planning and management: A critical review. World Dev. 1998, 26, 171-186. [CrossRef]

9. Barnett, T.P.; Pierce, D.W. When will Lake Mead go dry? Water Resour. Res. 2008, 44. [CrossRef]

10. Qureshi, M.E.; Grafton, R.Q.; Kirby, M.; Hanjra, M.A. Understanding irrigation water use efficiency at different scales for better policy reform: A case study of the Murray-Darling Basin, Australia. Water Policy 2011, 13, 1-17. [CrossRef]

11. Guo, W.; Fu, Y.; Ruan, B.; Ge, H.; Zhao, N. Agricultural non-point source pollution in the Yongding River Basin. Ecol. Indic. 2014, 36, 254-261. [CrossRef]

12. Jiang, B.; Wong, C.P.; Lu, F.; Ouyang, Z.; Wang, Y. Drivers of drying on the Yongding River in Beijing. J. Hydrol. 2014, 519, 69-79. [CrossRef]

13. Meng, L.; Chen, Y.; Li, W.; Zhao, R. Fuzzy comprehensive evaluation model for water resources carrying capacity in Tarim River Basin, Xinjiang, China. Chin. Geogr. Sci. 2009, 19, 89-95. [CrossRef]

14. Yang, G.; He, X.; Li, J. The evaluation method study for water resources sustainable utilization in arid areas. Int. J. Chem. Eng. Appl. 2010, 1, 359-362. [CrossRef]

15. Cui, Y.; Feng, P.; Jin, J.; Liu, L. Water Resources Carrying Capacity Evaluation and Diagnosis Based on Set Pair Analysis and Improved the Entropy Weight Method. Entropy 2018, 20, 359. [CrossRef] [PubMed] 
16. Wu, B.; Jiang, L.; Yan, N.; Perry, C.; Zeng, H. Basin-wide evapotranspiration management: Concept and practical application in Hai Basin, China. Agric. Water Manag. 2014, 145, 145-153. [CrossRef]

17. Feng, F.; Dong, G.; Zhang, W. Calculation of area target evapotranspiration in yellow river basin and evaluation of water resource allocation. Trans. Chin. Soc. Agric. Eng. 2014, 30, 101-111.

18. Jinxia, S.; Bin, L.; Shuqian, W.; Lingjun, L. Water Resources Management Based on the ET Control Theory. Procedia Eng. 2012, 28, 665-669. [CrossRef]

19. Gao, G.; Xu, C.-Y.; Chen, D.; Singh, V.P. Spatial and temporal characteristics of actual evapotranspiration over Haihe River basin in China. Stoch. Environ. Res. Risk Assess. 2011, 26, 655-669. [CrossRef]

20. Castle, S.L.; Reager, J.T.; Thomas, B.F.; Purdy, A.J.; Lo, M.H.; Famiglietti, J.S.; Tang, Q. Remote detection of water management impacts on evapotranspiration in the Colorado River Basin. Geophys. Res. Lett. 2016, 43, 5089-5097. [CrossRef]

21. Pan, Y.; Zhang, C.; Gong, H.; Yeh, P.J.F.; Shen, Y.; Guo, Y.; Huang, Z.; Li, X. Detection of human-induced evapotranspiration using GRACE satellite observations in the Haihe River basin of China. Geophys. Res. Lett. 2017, 44, 190-199. [CrossRef]

22. Wu, B.; Zeng, H.; Yan, N.; Zhang, M. Approach for Estimating Available Consumable Water for Human Activities in a River Basin. Water Resour. Manag. 2018, 32, 2353-2368. [CrossRef]

23. Ahmad, M.-u.-D.; Bastiaanssen, W.G.M.; Feddes, R.A. A new technique to estimate net groundwater use across large irrigated areas by combining remote sensing and water balance approaches, Rechna Doab, Pakistan. Hydrogeol. J. 2004, 13, 653-664. [CrossRef]

24. van Eekelen, M.W.; Bastiaanssen, W.G.M.; Jarmain, C.; Jackson, B.; Ferreira, F.; van der Zaag, P.; Saraiva Okello, A.; Bosch, J.; Dye, P.; Bastidas-Obando, E.; et al. A novel approach to estimate direct and indirect water withdrawals from satellite measurements: A case study from the Incomati basin. Agric. Ecosyst. Environ. 2015, 200, 126-142. [CrossRef]

25. Grafton, R.Q.; Williams, J.; Perry, C.; Molle, F.; Ringler, C.; Steduto, P.; Udall, B.; Wheeler, S.; Wang, Y.; Garrick, D. The paradox of irrigation efficiency. Science 2018, 361, 748-750. [CrossRef] [PubMed]

26. Surridge, B.; Harris, B. Science-driven integrated river basin management: A mirage? Interdiscip. Sci. Rev. 2013, 32, 298-312. [CrossRef]

27. Brebbia, C.A.; Popov, R. Water Resources Management V. Int. J. Des. Nat. Ecodyn. 2010, 5, 87.

28. Sun, T.; Xu, J.; Yang, Z.F. Environmental flow assessments in estuaries based on an integrated multi-objective method. Hydrol. Earth Syst. Sci. 2013, 17, 751-760. [CrossRef]

29. Poff, N.L.; Richter, B.D.; Arthington, A.H.; Bunn, S.E.; Naiman, R.J.; Kendy, E.; Acreman, M.; Apse, C.; Bledsoe, B.P.; Freeman, M.C.; et al. The ecological limits of hydrologic alteration (ELOHA): A new framework for developing regional environmental flow standards. Freshw. Biol. 2010, 55, 147-170. [CrossRef]

30. Poff, N.L.; Brown, C.M.; Grantham, T.E.; Matthews, J.H.; Palmer, M.A.; Spence, C.M.; Wilby, R.L.; Haasnoot, M.; Mendoza, G.F.; Dominique, K.C.; et al. Sustainable water management under future uncertainty with eco-engineering decision scaling. Nat. Clim. Chang. 2015, 6, 25-34. [CrossRef]

31. Bojie, F. Early warning theory on regional eco-environmental issues and its application. Chin. J. Appl. Ecol. 1993, 4, 436-439.

32. Brekke, L.; Larsen, M.D.; Ausburn, M.; Takaichi, L. Suburban water demand modeling using stepwise regression. J.-Am. Water Work. Assoc. 2002, 94, 65-75. [CrossRef]

33. Day, D.; Howe, C. Forecasting peak demand-what do we need to know? Water Sci. Technol. Water Supply 2003, 3, 177-184. [CrossRef]

34. Shvartser, L.; Shamir, U.; Feldman, M. Forecasting Hourly Water Demands by Pattern Recognition Approach. J. Water Resour. Plan. Manag. 1993, 119, 611-627. [CrossRef]

35. Zhou, S.; McMahon, T.; Walton, A.; Lewis, J. Forecasting operational demand for an urban water supply zone. J. Hydrol. 2002, 259, 189-202. [CrossRef]

36. Deng, X.; Zhang, F.; Wang, Z.; Li, X.; Zhang, T. An Extended Input Output Table Compiled for Analyzing Water Demand and Consumption at County Level in China. Sustainability 2014, 6, 3301-3320. [CrossRef]

37. Jain, A.; Ormsbee, L.E. Short-term water demand forecast modeling techniques-Conventional methods versus AI. J.-Am. Water Work. Assoc. 2002, 94, 64-72. [CrossRef]

38. Zarghami, M.; Abrishamchi, A.; Ardakanian, R. Multi-criteria decision making for integrated urban water management. Water Resour. Manag. 2008, 22, 1017-1029. [CrossRef]

39. Zhou, J.; Civco, D.L.; Silander, J.A. A wavelet transform method to merge Landsat TM and SPOT panchromatic data. Int. J. Remote Sens. 2010, 19, 743-757. [CrossRef]

40. Huffman, G.J.; Adler, R.F.; Morrissey, M.M.; Bolvin, D.T.; Curtis, S.; Joyce, R.; McGavock, B.; Susskind, J. Global Precipitation at One-Degree Daily Resolution from Multisatellite Observations. J. Hydrometeorol. 2001, 2, 36-50. [CrossRef]

41. Wang, M.; Du, L.; Ke, Y.; Huang, M.; Zhang, J.; Zhao, Y.; Li, X.; Gong, H. Impact of climate variabilities and human activities on surface water extents in reservoirs of Yongding River Basin, China, from 1985 to 2016 based on Landsat observations and time series analysis. Remote Sens. 2019, 11, 560. [CrossRef]

42. Wang, Y.; Zhang, S.; Cui, W.; Meng, X.; Tang, X. Polycyclic aromatic hydrocarbons and organochlorine pesticides in surface water from the Yongding River basin, China: Seasonal distribution, source apportionment, and potential risk assessment. Sci. Total Environ. 2018, 618, 419-429. [CrossRef] [PubMed] 
43. Wolff, D.B.; Nelkin, E.J.; Bolvin, D.T.; Huffman, G.J.; Adler, R.F.; Gu, G.; Hong, Y.; Bowman, K.P.; Stocker, E.F. The TRMM Multisatellite Precipitation Analysis (TMPA): Quasi-Global, Multiyear, Combined-Sensor Precipitation Estimates at Fine Scales. J. Hydrometeorol. 2007, 8, 38-55. [CrossRef]

44. Cheema, M.J.M.; Bastiaanssen, W.G.M. Local calibration of remotely sensed rainfall from the TRMM satellite for different periods and spatial scales in the Indus Basin. Int. J. Remote Sens. 2011, 33, 2603-2627. [CrossRef]

45. Duan, Z.; Bastiaanssen, W.G.M. First results from Version 7 TRMM 3B43 precipitation product in combination with a new downscaling-calibration procedure. Remote Sens. Environ. 2013, 131, 1-13. [CrossRef]

46. Wu, B.; Xiong, J.; Yan, N.; Yang, L. ETWatch: An Operational ET Monitoring System with Remote Sensing. In Proceedings of the 2008 ISPRS Workshop on Geo-Information and Decision Support Systems, Tehran, Iran, 6-7 January 2008.

47. Jia, Z.; Liu, S.; Xu, Z.; Chen, Y.; Zhu, M. Validation of remotely sensed evapotranspiration over the Hai River Basin, China. J. Geophys. Res. Atmos. 2012, 117. [CrossRef]

48. Wu, B.; Yan, N.; Xiong, J.; Bastiaanssen, W.; Zhu, W.; Stein, A. Validation of ETWatch using field measurements at diverse landscapes: A case study in Hai Basin of China. J. Hydrol. 2012, 436, 67-80. [CrossRef]

49. Lu, Y.; Wu, B.; Yan, N.; Zhu, W.; Zeng, H.; Ma, Z.; Xu, J.; Wu, X.; Pang, B. Quantifying the Contributions of Environmental Factors to Wind Characteristics over 2000-2019 in China. ISPRS Int. J. Geo-Inf. 2021, 10, 515. [CrossRef]

50. Wu, B.; Qian, J.; Zeng, Y.; Zhang, L.; Yan, C.; Wang, Z.; Li, A.; Ma, R.; Yu, X.; Huang, J. Land Cover Atlas of the People's Republic of China (1: 1000 000); Science Bulletin 65; China Map Publishing House: Beijing, China, 2017.

51. Ouyang, Z.; Zheng, H.; Xiao, Y.; Polasky, S.; Liu, J.; Xu, W.; Wang, Q.; Zhang, L.; Xiao, Y.; Rao, E. Improvements in ecosystem services from investments in natural capital. Science 2016, 352, 1455-1459. [CrossRef]

52. Wu, F.; Wu, B.; Zhu, W.; Yan, N.; Xu, J. ETWatch Cloud: APIs for regional actual evapotranspiration data generation. Environ. Model. Softw. 2021, 145, 105174. [CrossRef]

53. Wu, B.; Yan, N.; Jiang, L.; Chang, S. A method of water consumption balance and application. Yaogan Xuebao J. Remote Sens. 2011, 15, 281-297.

54. Bastiaanssen, W.; Karimi, P.; Rebelo, L.-M.; Duan, Z.; Senay, G.; Muthuwatte, L.; Smakhtin, V. Earth Observation Based Assessment of the Water Production and Water Consumption of Nile Basin Agro-Ecosystems. Remote Sens. 2014, 6, 10306-10334. [CrossRef]

55. Song, X.P.; Hansen, M.C.; Stehman, S.V.; Potapov, P.V.; Tyukavina, A.; Vermote, E.F.; Townshend, J.R. Global land change from 1982 to 2016. Nature 2018, 560, 639-643. [CrossRef] [PubMed]

56. Rodell, M. Basin scale estimates of evapotranspiration using GRACE and other observations. Geophys. Res. Lett. 2004, 31. [CrossRef]

57. Rodell, M.; Velicogna, I.; Famiglietti, J.S. Satellite-based estimates of groundwater depletion in India. Nature 2009, 460, 999-1002. [CrossRef]

58. Feng, W.; Zhong, M.; Lemoine, J.-M.; Biancale, R.; Hsu, H.-T.; Xia, J. Evaluation of groundwater depletion in North China using the Gravity Recovery and Climate Experiment (GRACE) data and ground-based measurements. Water Resour. Res. 2013, 49, 2110-2118. [CrossRef]

59. Castle, S.L.; Thomas, B.F.; Reager, J.T.; Rodell, M.; Swenson, S.C.; Famiglietti, J.S. Groundwater depletion during drought threatens future water security of the Colorado River Basin. Geophys. Res. Lett. 2014, 41, 5904-5911. [CrossRef]

60. Famiglietti, J.S. The global groundwater crisis. Nat. Clim. Chang. 2014, 4, 945-948. [CrossRef]

61. Pullinger, M.; Browne, A.; Anderson, B.; Medd, W. Patterns of Water: The Water Related Practices of Households in Southern England, and Their Influence on Water Consumption and Demand Management. 2013. Available online: http:/ / eprints.soton.ac. uk/id/eprint/359514 (accessed on 30 June 2020). 